\title{
日本語文章における表層表現と用例を用いた 動詞の省略の補完
}

\begin{abstract}
村田 真樹 ${ }^{\dagger}$ 長 尾 真 ${ }^{\dagger}$
自然言語では，動詞を省略するということがある。この省略された動詞を復元するこ とは，対話システムや高品質の機械翻訳システムの実現には不可欠なことである．そ こで本研究では，この省略された動詞を表層の表現 (手がかり語) と用例から補完する ことを行なう．解析のための規則を作成する際，動詞の省略現象を補完する動詞がテ キスト内にあるかいなかなどで分類した。 小説を対象にして実験を行なったところ， テストサンプルで再現率 $84 \%$, 適合率 $82 \%$ の精度で解析できた. このことは本手法 が有効であることを示している，テキスト内に補完すべき動詞がある場合は非常に精 度が良かった。それに比べ，テキスト内に補完すべき動詞がない場合はあまり良くな かった。しかし，テキスト内に補完すべき動詞がない場合の問題の難しさから考える と，少しでも解析できるだけでも価值がある，また，コーパスが多くなり，計算機の 性能もあがり大規模なコーパスが利用できるようになった際には, 本稿で提案した用 例を利用する手法は重要になるだろう。
\end{abstract}

キーワード：動詞，省略，表層表現，用例

\section{Resolution of Verb Phrase Ellipsis in Japanese Sentences using Surface Expressions and Examples}

\author{
MASAKI MURATA ${ }^{\dagger}$ and MAKOTO NAGAO ${ }^{\dagger}$
}

Verb phrases are sometimes omitted in natural language (ellipsis). It is necessary to resolve the verb phrase ellipses in language understanding, machine translation, and dialogue processing. This paper describes a practical way to resolve verb phrase ellipses by using surface expressions and examples. To make heuristic rules for ellipsis resolution we classified verb phrase ellipses by checking whether the referent of a verb phrase ellipsis appears in the surrounding sentences or not. We experimented with the resolution of verb phrase elipses on a novel and obtained a recall rate of $84 \%$ and a precision rate of $82 \%$ on test sentences. This indicates that our method is effective. In the case when the referent of a verb phrase ellipsis appeared in the surrounding sentences, the accuracy rate was very high. But, in the case when the referent of a verb phrase ellipsis did not appear in the surrounding sentences, the accuracy rate was not so high. Since the analysis of this phenomena is very difficult, it is valuable to propose a way of solving the problem to a certain extent. When the size of corpus becomes larger and the machine performance becomes greater, the method of using corpus will become effective.

KeyWords: Verb, Ellipsis, Surface Expression, Example

†京都大学工学部 電子通信工学教室, Department of Electronics and Communication, Kyoto University 


\begin{tabular}{|c|c|c|}
\hline & 一致部分 & 後続部分 \\
\hline こんなに & うまくいくとは & 思えない。 \\
\hline いつも & うまくいくとは & 限らない。 \\
\hline 完全に & うまくいくとは & いえない。 \\
\hline
\end{tabular}

図 1 コーパスにおける「うまくいくとは」を含む文の例

\section{1 はじめに}

自然言語文には動詞を省略した文が存在する。この省略された動詞を復元することは，対話 システムや高品質の機械翻訳システムの実現には不可欠なことである．そこで本研究では，こ の省略された動詞を表層表現と用例から補完することを行なう。

表層表現とは，文章の表層に現れる手がかり表現のことである．例えば，助詞の「も」で文 が終っている省略文の場合，助詞の「も」という手がかり語のおかげで前文の繰り返しであろ うと推測でき，前文の文末の動詞を補えばよいとわかる。この表層表現を用いる手法は，応用 範囲の大きい手法であり，解析したい問題があるとき，そのための手がかりとなる言語表現が その問題の近くに存在することが多く，それを用いることでその問題が解析可能となる.

用例とは，人間が実際に使用した自然言語文のことである．用例を用いた動詞の補完方法の 一例を以下にあげる，例えば,「そううまくいくとは」の文に動詞を補いたいとするとき，「そj うまくいくとは」を含む文 (用例) を大量の文章 (コーパス) から取り出し (図 1),「そううまくい くとは」に続く部分（この場合，「思えない」「限らない」など）を補完するということを行なう. この用例を用いる手法も，応用範囲の大きい手法であり，解析したい問題とよく似た形の用例 を探してくれば，すぐにでも用いることができるものである.

以上のように表層表現と用例はともに応用範囲の広い方法であり，かつ，現在の自然言語技 術でも十分に用いることができる便利な手法である。本稿はこの表層表現と用例を用いて動詞 の補完を試みたものである.

本研究は先行研究に対し以下の点において新しさがある.

・ 日本語の動詞の省略の補完の研究はいままでほとんどなされていなかった.

・ 英語については動詞の省略を扱った研究はたくさんあるが，それらは補うべき動詞が わかっているときにどういう構文構造で補完するべきかを扱っており, 補う動詞を推 定する研究はほとんどなされていない (Dalrymple, Shieber, and Pereira 1991)(Kehler 1993)(Lappin and Shih 1996). それに対し，本研究は省略された動詞を推定することを 扱っている.

・ 補うべき動詞が文中にないことがあり，システムが知識を用いて補うべき動詞をつくり 


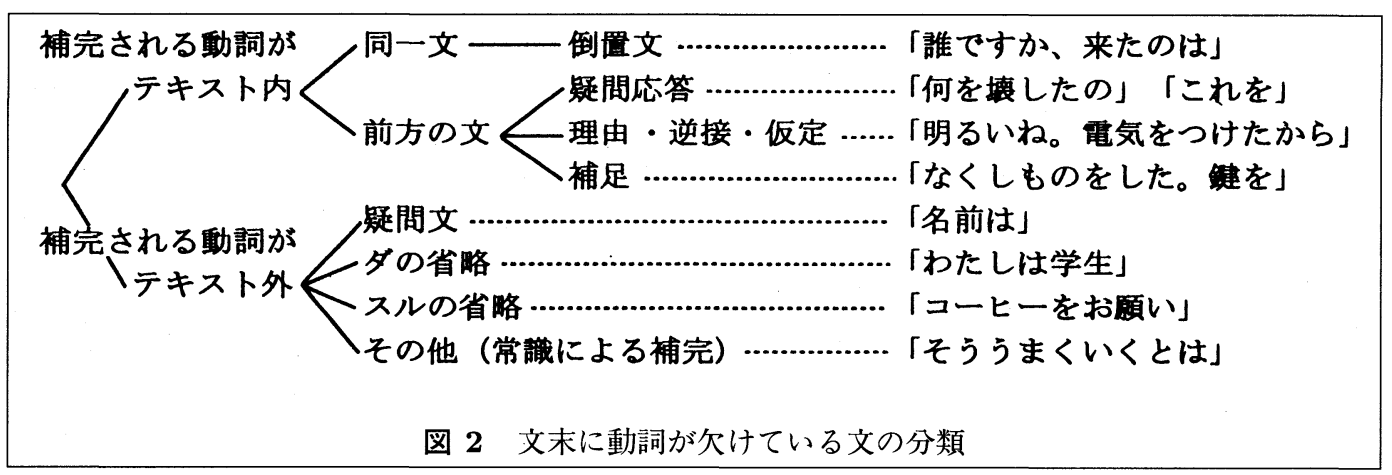

出さなければならないことがある．本研究ではこの問題に対し用例を用いる方法で対処 している.

\section{2 動詞の省略現象の分類}

本研究は，動詞の省略現象として文末の省略現象についてのみ対象とする．文の内部で省略 されることもあるが，それらは統語的な問題として処理されるであろうとし，本研究の対象外 とした.

本研究では，処理の観点から文末において動詞が欠けている文の分類を行なった。その分類 を図 2 に示す。これは，まず，補完する動詞がある位置から分類し，最後に省略現象の意味から 分類したものである，倒置は省略ではないが，文末において動詞が欠けているという意味から 本稿の対象内としている.

この分類はまだまだ修正する必要があり不完全なものであるが，処理の観点から文末の動詞 の省略現象を把握する場合には役に立つものであると考えている.

以降の節では文末の省略現象のそれぞれの分類ごとに，その現象の特徴とおおよその解析方 法を述べる.

\section{1 テキスト内から補完される省略現象}

\section{倒置文}

倒置文は多くの場合，終止形などの普通に文末となりうる表現が文の途中にあり，この部分 を中心にして文が倒置されている，例えば，以下の文では「誰ですか」が普通に文末となりう る表現であり，この部分を中心にして文が倒置されている。

「誰ですか、来たのは」

このため, 倒置文の解析は, 終止形などの普通に文末となりうる表現が読点を伴って文の途 
中にある場合，その部分で倒置された倒置文と判断するということで行なう ${ }^{1}$. 例えば，上の例 文では「誰ですか」が普通に文末となりうる表現であり，その部分で倒置された倒置文である と判断される.

\section{疑問応答}

疑問一応答という文の対において疑問と応答で同一の動詞を使用する際，応答側の文の動詞 が省略される場合がある，例えば，以下の例文では「これを」の動詞が省略されているが，そ の省略部分に入る動詞は疑問側の「壊した」である。

「何を壊したの」「これを」

このため, この種の文の解析は, 疑問一応答を形成しているかどうかを「何」などの表現に よって検出し, 疑問一応答であることがわかれば, 疑問側の文の動詞を補完するということを行 なう.

\section{理由・逆接・仮定}

文末に動詞が欠けている文の中には, 文末が接続助詞で終っており, 前文と理由・逆接・仮 定という意味関係で，ある種，文をまたがった倒置となっているものがある2 . 例えば，以下の 文の場合,「電気をつけたから」の部分が前文の「明るいね」の部分の理由になっており，文を いれかえて解釈すると意味の通った文となる。

「明るいね。電気をつけたから」

このような場合の解析は, 基本的には文末が接続助詞で終了している場合は前文と意味関係 にあると判定し, 前文と文の順序を入れかえて解釈する.しかし，逆接の場合は単に以下のよ うに以降の発話に余韻を持たせるために用いるだけで前文に対して逆接の関係にならない場合 もある。

$$
\text { 「お聞きしていいのかわかりませんが」 }
$$

そこで，逆接の接続詞の場合は前文と関係を持ちやすい「のに」の場合は前文と関係があると し，それ以外の接続助詞の場合は以降の発話に対して余韻を持たせていると判定する.

1 倒置文の解析は, 本来は文献 (山本, 小林, 中川 1992) にあるように構文解析が成功するか否かなどの情報を用いて行な うべきである.しかし，本研究で利用した構文解析システムはかかり受けの構造を出力するものであり，本研究の実験 で用いるデー夕は構文情報を修正したものであり倒置文であってもかかり受けの構造で表現されており, 構文解析が成 功するか否かの情報を利用することができない.このため, 本研究では表層の言語表現を用いて解析した.

2 接続助詞で終っている文がすべてこの分類となるわけではない. 前文に対して倒置になっておらず，テキストにない動 詞を補う必要があるものもある。これらは，2.2節の「その他(常識による補完)」で扱われることになる。 


\section{補足}

前文の補足としての役割をする文で，動詞の省略が行なわれることがある．例えば，以下の 例文は，ものをなくしたけれども，鍵をなくしたということを補足的に述べている.

$$
\text { 「物をなくした。鍵を」 }
$$

この種の解析には単語の意味を利用する方法として以下の二種類の方法を考えた。一つは, 省略された文と前文とで同じ格要素に来る単語の意味が近ければ，それらは対応関係にあって動 詞の省略された部分には，前文の動詞が補完されるというものである．この場合，「物」と「鍵」 は同じ具体物という意味で意味的に近いので対応関係にあると認定され，「鍵を」に対して補完 する動詞は「なくした」となる。

もう一つは以下のように前文の動詞の対応する格要素の部分がゼロ代名詞化した場合のため の方法である。

$$
\text { 「なくした。鍵を」 }
$$

この例の場合は，動詞「なくす」の格フレームを用い，格フレームのヨ格の要素になりやすい 単語 ${ }^{3}$ 「鍵」を比較し，意味的に近ければ「鍵を」が「なくした.」のヨ格の要素にくると判定 し,「鍵を」に補う動詞は「なくした.」となる。

また，表層表現を用いる規則があり，反復を示す助詞「も」などの手がかり語が存在する場 合は前の文の補足と判定する.

前文の補足関係となる動詞の省略現象は以上の他にも多数あり，本研究での解析方法では手 がかりがなければ前文の文末の動詞を補うということを行なっている.

\section{2 テキスト外から補完される省略現象}

\section{疑問文}

疑問文では提題助詞「は」で終了して動詞を省略する場合がある，例えば，以下の例は相手 の名前を聞いているときの発話である.

「名前は」

このように“名詞十「は」”の形になっている場合は疑問になっていることが多い。そこで， 本研究では “名詞+「は」”の形で終っている場合は，疑問と判定した4。

3 IPAL の格フレーム辞書 (情報処理振興事業協会技術センター 1987) にはそれぞれの格要素にどういう単語が入りうる かの情報が記載されている。本研究ではこれを利用する.

4 本研究は省略された動詞の補完なので,「何といいますか」といった表現を補いたいところだが, これらは疑問の内容に よって変化するので, 生成の問題であると判断し, 本稿では扱っていない. 


\section{ダの省略}

文が名詞で終了している場合，判定詞「だ」の省略が行なわれていることがある.

$$
\text { 「わたしは学生」 }
$$

この例は「わたしは学生です」という文で判定詞「だ」または「です」の省略を行なったもの である。

この種の解析は文が名詞で終了しているか否かを調べたり, 主語が存在しているなどの文構 造を利用したりして行なえばよい。

\section{スルの省略}

文末がサ変名詞である場合,「する」「します」が省略されていることがある.

$$
\text { 「コーヒーをお願い」 }
$$

これの例は「コーヒーをお願いします」という文で「します」を省略したものである.

この解析は, 文末がサ変動詞「する」が接続可能なサ変名詞であるかどうかやサ変名詞に対 して連体修飾語が存在していないかどうかを調べることによって行なう。

\section{その他 (常識による補完)}

前の三つの「疑問文」「ダの省略」「スルの省略」の他にテキスト外補完の場合の省略例とし て以下のものがある.

$$
\text { 「じつは、ちょつとお願いが…...」 }
$$

この種の省略現象は補うものがテキスト内に無いうえ，補完される言語表現が多岐にわたって おり，解析が難しい現象である。

本研究ではこの問題の解決するために大規模なコーパス (解析をしていないもの) を利用し て補完内容を推定する，上の例文を人間が読むと省略された動詞が「あります」であることが 自然とわかる。これは, 頭の中に「じつは、ちょつとお願いがあります」という文が経験的知識 となって存在しているからである。これと同じようなことをコーパスを用いて行なうとすると， 「じつは、ちょつとお願いが」とできるだけ意味的に近い表現をコーパス中から抽出し，抽出し た文の「じつは、ちょつとお願いが」の次の部分がおおよそ省略部分の内容であることが予想 され，それを補完するということを行なえばよいことがわかる．本研究では，以上の方法で解 析する.ただし, 意味的に近い表現を抽出するところは, 現在の自然言語技術では困難なので, 文末の文字列を最長に含む文を抽出するということで近似している. 


\section{条件部 $\Rightarrow\{$ 提案 提案 .. $\}$ \\ 提案 :=( 解の候補 得点 )}

図 3 規則の表現

\section{3 照応処理システム}

\section{1 システムの枠組}

本研究では，動詞の省略現象の解析を行なう際，名詞，指示詞，代名詞，ゼロ代名詞などに よる照応の解析も同時に行なう。まず，解析する文章を構文解析・格解析する (Kurohashi and Nagao 1994)。 その結果に対して文章の初めから動詞の省略の補完を行なう。省略の補完は，省 略の補完の手がかりとなる複数の情報をそれぞれ規則にし，これらの規則を用いて解の候補に 得点を与えて, 合計点が最も高い解の候補をシステムの解とすることによって実現する。この 合計点を利用する方式は，以下の原理に基づいている．照応解析のように複雑な問題では，複 数の情報が絡み合っており複数の情報を総合的に判断することにより解析を行なう必要がある. この複数の情報を総合的に判断するということを各規則の得点の和という形で実現し，合計点 の最も高い候補をシステムの解としている，規則に応じて候補に得点を足していく操作は，そ の候補が解であるという確信度が高まっていくことに対応している．また，得点によりどの規 則を優先すべきかを指定することができるようになっている ${ }^{5}$.

規則は，困3の構造をしている，図中の「条件部」には文章中のあらゆる語やその分類語彙 表 (国立国語研究所 1964) の分類番号や IPAL の格フレーム (情報処理振興事業協会技術セン ター 1987) の情報や構文解析・格解析の結果の情報などを条件として書くことができる.「解の 候補」には補完対象の動詞の位置や補完したい動詞などを書くことができる。「得点」は解とし ての適切さの度合を表している。

\section{2 動詞の省略現象の解析}

動詞の省略の補完のために規則を 22 個作成したが，これらすべてを表 $1 に$ 示す。これらの 規則は文献 (川合 1982)(高橋 1993) を参考にしたり 4.1節で述べる学習サンプルを見たりして人 手で作成した，各規則で与える得点は，規則の優劣を考慮して人手で定めたり，学習サンプル で実験的に人手で定めたりした。

5 指示詞の指示先などの推定の場合文章中での物理的距離，意味的制約における意味の近さなど数值化せずには扱いにく いものが多数存在していたが, 本研究の動詞の省略では数值化の必要性がある規則があまり存在せず規則の間の関係も それほど複雑でないので，得点を使わずに単純な if-then ルールによる方式でも十分であったが，われわれは照応処理 の統合を考えておりわれわれの他の照応処理の研究 (村田·長尾 1996)(村田·長尾 1997a)(村田・長尾 1997b) と同様 な方式で解析を行ないたかったため，合計点を利用する方式を採用した。 
表 1 動詞の補完のための規則

\begin{tabular}{|c|c|c|c|c|}
\hline 順序 & 条件部 & 解の候補 & 得点 & 例文 \\
\hline \multicolumn{5}{|c|}{ 動詞の省略はないと判定する場合の規則 } \\
\hline 1 & $\begin{array}{l}\text { 文末が動詞の終止形, 過去形, 推 } \\
\text { 量形, 意志形, 命令形の基本形な } \\
\text { どで終了している場合か, 終助詞 } \\
\text { で終了している場合 }\end{array}$ & 動詞の省略はない & 30 & その湖は、北の国にあった。 \\
\hline 2 & $\begin{array}{l}\text { 人名,もしくは, 人を意味する単 } \\
\text { 語で終了している場合 }\end{array}$ & $\begin{array}{l}\text { よびかけであり, 動詞の } \\
\text { 省略はないと解釈する }\end{array}$ & 30 & 「はい、先生」 \\
\hline 3 & $\begin{array}{l}\text { 文末が基本連用形，もしくは,「て」 } \\
\text { で終る連用形であり，引用文内の } \\
\text { 場合 }\end{array}$ & $\begin{array}{l}\text { 命令文と解釈し, 動詞の } \\
\text { 省略はないと解釈する }\end{array}$ & 30 & 「さあ、目をつぶって」 \\
\hline 4 & $\begin{array}{l}\text { 文末が「が」などの逆接の接続助 } \\
\text { 詞である場合 }\end{array}$ & $\begin{array}{l}\text { 動詞の補完の必要のない } \\
\text { 逆接と解釈する }\end{array}$ & 5 & $\begin{array}{l}\text { 「お聞きしていいのかわかりま } \\
\text { せんが」 }\end{array}$ \\
\hline \multicolumn{5}{|c|}{ 倒置の場合の規則 } \\
\hline 5 & $\begin{array}{l}\text { 同一文に用言の基本形などの文末 } \\
\text { になりうる表現が読点を伴って存 } \\
\text { 在する場合 }\end{array}$ & $\begin{array}{l}\text { その部分で倒置された倒 } \\
\text { 置文と解釈する }\end{array}$ & 10 & $\begin{array}{l}\text { 「それで見つかったのか、約束 } \\
\text { の相手は」 }\end{array}$ \\
\hline \multicolumn{5}{|c|}{ 質問-応答の場合の規則 } \\
\hline 6 & $\begin{array}{l}\text { 「どうぞ」「はい」などの応答を } \\
\text { 示す表現が文内にあって前文の文 } \\
\text { 末に疑問を示す「か」などがある } \\
\text { 場合 }\end{array}$ & 疑問文の文末の動詞 & 5 & $\begin{array}{l}\text { 「近よって観察してもいいでしょ } \\
\text { うか」「どうぞ、ご自由に…… }\end{array}$ \\
\hline 7 & $\begin{array}{l}\text { 前方 } 3 \text { 文以内に「だれ」「何」な } \\
\text { どの疑問詞がある場合 }\end{array}$ & 疑問詞がかかる動詞 & 5 & $\begin{array}{l}\text { 「だれを殺したんだ」「サルです。 } \\
\text { わたしの飼っていたサルを(殺し } \\
\text { たのです)」と、男が答えた。 }\end{array}$ \\
\hline \multicolumn{5}{|c|}{ 理由・逆接・仮定の場合の規則 } \\
\hline 8 & 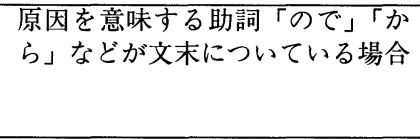 & $\begin{array}{l}\text { 現在の文を前文の理由を } \\
\text { 示す文であると解勫する. }\end{array}$ & 5 & $\begin{array}{l}\text { 「穴を埋めていただくのはあり } \\
\text { がたいが、その土地をあげるわ } \\
\text { けにはいかない。そこに、社を } \\
\text { 建てなくてはならないんだから」 }\end{array}$ \\
\hline 9 & $\begin{array}{l}\text { 文末が「のに」などの逆接の接続 } \\
\text { 助詞である場合 }\end{array}$ & $\begin{array}{l}\text { 現在の文に対して前文が } \\
\text { 逆接の関係でつながって } \\
\text { いると解釈する }\end{array}$ & 5 & $\begin{array}{l}\text { 「これが悪魔とはねえ。もう少 } \\
\text { し堂々としたもの思ってい } \\
\text { たのに」 }\end{array}$ \\
\hline 10 & $\begin{array}{l}\text { 文末が動詞の条件形か仮定を表わ } \\
\text { す助詞である場合 }\end{array}$ & $\begin{array}{l}\text { 現在の文を前文の仮定を } \\
\text { 示す文であると解釈する. }\end{array}$ & 5 & $\begin{array}{l}\text { 「それなら、いいじゃないか。な } \\
\text { にも、交番にまで来て大さわぎ } \\
\text { しなくても」 }\end{array}$ \\
\hline \multicolumn{5}{|c|}{ 補足の場合の規則 } \\
\hline 11 & $\begin{array}{l}\text { 文末が連用形であり, 引用文内で } \\
\text { ない場合 }\end{array}$ & $\begin{array}{l}\text { 前文の補足の文と解釈し, } \\
\text { 前文の文末の動詞を補完 } \\
\text { する }\end{array}$ & 5 & $\begin{array}{l}\text { 召使は部屋に入り、えさを取り } \\
\text { かえた。主人がよく与えていた } \\
\text { シュークリームも加えて。 }\end{array}$ \\
\hline 12 & 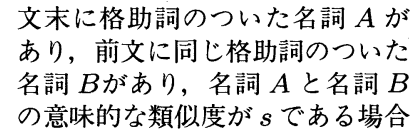 & 名詞 Bがかかる動詞 & $\begin{array}{l}s * 20 \\
-2\end{array}$ & $\begin{array}{l}\text { いまでは、すべての悪がなくなっ } \\
\text { ている。強盗だとか詐欺な゙とか、 } \\
\text { あらゆる犯罪が(なくなってい } \\
\text { る)。 }\end{array}$ \\
\hline
\end{tabular}


表 1. 動詞の補完のための規則 (つづき)

\begin{tabular}{|c|c|c|c|c|}
\hline 順序 & 条件部 & 解の候補 & 得点 & 例文 \\
\hline \multicolumn{5}{|c|}{ 補足の場合の規則 } \\
\hline 13 & 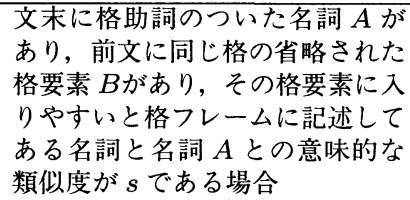 & 格要素 $\bar{B}$ を持つ動詞 & $\begin{array}{l}s * 20 \\
-2\end{array}$ & $\begin{array}{l}\text { 私は同僚に ( を) 指さしてみ } \\
\text { せた。バラをからませた垣根の } \\
\text { なかの、大きなニレの樹の下に } \\
\text { ある古風なつくりの住宅を。 }\end{array}$ \\
\hline 14 & $\begin{array}{l}\text { 文末が名詞接続助詞「も」である } \\
\text { か,「もっとも」などの繰り返しを } \\
\text { 想起しやすい副詞が文中に存在す } \\
\text { る場合 }\end{array}$ & $\begin{array}{l}\text { 同一発話者の前文の繰り } \\
\text { 返しと解釈し, 同一発話 } \\
\text { 者の前文の文末の動詞を } \\
\text { 補完する }\end{array}$ & 5 & $\begin{array}{l}\text { 「大人って悪いことばかりして } \\
\text { いるんだよ。よくかんないけ } \\
\text { れど、ワイロなんてことも….. }\end{array}$ \\
\hline 15 & 前文が疑問文の場合 & 前文の文末の動詞 & 1 & \\
\hline 16 & $\begin{array}{l}\text { いつでも適用される規則 (他の規 } \\
\text { 則が適用されない場合のデフォル } \\
\text { ト規則) }\end{array}$ & 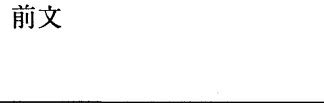 & 0 & \\
\hline \multicolumn{5}{|c|}{ 疑問文の場合の規則 } \\
\hline 17 & $\begin{array}{l}\text { 文末が助詞「は」がつく名詞であ } \\
\text { る場合 }\end{array}$ & 疑問文と解釈する & 3 & 「名前は」 \\
\hline \multicolumn{5}{|c|}{ 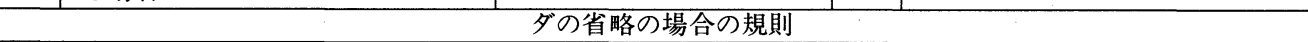 } \\
\hline 18 & $\begin{array}{l}\text { 文末が名詞，もしくは，名詞接続 } \\
\text { 助詞「ばかり」「だけ」などであ } \\
\eta ， \text { 文中に主語に相当する名詞接 } \\
\text { 続助詞「は」「も」「が」がつく名 } \\
\text { 詞がある場合 }\end{array}$ & $\begin{array}{l}\text { 判定詞「です」の省略と } \\
\text { 解釈し,「です」を補完す } \\
\text { る }\end{array}$ & 2 & $\begin{array}{l}\text { 「これはわたしの、ちょっとした } \\
\text { かんちがい」 }\end{array}$ \\
\hline 19 & 文末が時間を意味する名詞の場合 & $\begin{array}{l}\text { 判定詞「のことです」の } \\
\text { 省略と解釈し,「のことで } \\
\text { す」を補完する }\end{array}$ & 5 & そして、その次の夏。 \\
\hline 20 & $\begin{array}{l}\text { 文末が名詞, もしくは, 名詞接続 } \\
\text { 助詞「ばかり」「だけ」などであ } \\
\text { る場合 }\end{array}$ & $\begin{array}{l}\text { 判定詞「です」の省略と } \\
\text { 解釈し,「です」を補完す } \\
\text { る }\end{array}$ & 1 & 攻撃の命令を待つばかり。 \\
\hline \multicolumn{5}{|c|}{ スルの省略の場合の規則 } \\
\hline 21 & $\begin{array}{l}\text { 文末が連体修飾語を持たないサ変 } \\
\text { 名詞か動詞の連用形が名詞化した } \\
\text { ものである場合 }\end{array}$ & $\begin{array}{l}\text { 「します」の省略と解釈 } \\
\text { し,「します」を補完する }\end{array}$ & 2 & それを神さまあつかい。 \\
\hline \multicolumn{5}{|c|}{ 常識から補完する場合の規則 } \\
\hline 22 & $\begin{array}{l}\text { 文末の部分文字列を最長に含む文 } \\
\text { をコーパスから取り出せる場合. } \\
\text { その取り出した文において文字列 } \\
\text { 一致した部分の後方に来る表現の } \\
\text { うち最も多く出現したものの頻度 } \\
\text { が二番目のものよりも際だって大 } \\
\text { きい場合 (二番目に多く出現した } \\
\text { もの頻度の二倍以上の場合) は, } \\
9 \text { 点を与え, そうでない場合は } 1 \\
\text { 点を与える. }\end{array}$ & $\begin{array}{l}\text { 取り出した文において文 } \\
\text { 字列一致した部分の後方 } \\
\text { に来る表現のうち最も多 } \\
\text { く出現したもの (頻度最 } \\
\text { 大のものが複数個ある場 } \\
\text { 合は最初に取り出された } \\
\text { もの) }\end{array}$ & & $\begin{array}{l}\text { 「そううまくいくとは(思えな } \\
\text { い)」 }\end{array}$ \\
\hline
\end{tabular}


また，名詞・代名詞の照応解析も同時に解析するが，このための規則については文献 (村田 . 長尾 1996)(村田・長尾 1997a)(村田・長尾 1997b) を参照のこと.

表 1中の規則において，人を意味する単語の判定は，意味素性辞書 (渡辺, 黒橋, 長尾 1992) において意味素性 HUM が付与されている単語を，それとすることで行なった．また，時間を 意味する名詞の把握は, 意味素性辞書で TIM が付与されているか, 形態素解析結果として時相 名詞と解析されているものを，それとすることで行なった。

規則 1 は特別な規則で，この規則が適用された時は他の規則は適用されないようになって いる。

規則 12,13 の $s$ は，EDR 概念辞書における名詞 $A$ と名詞 $B$ の類似度により与えられる。こ

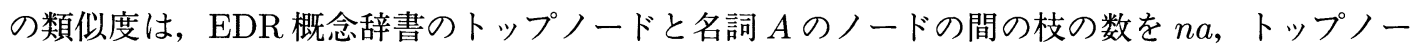
ドと名詞 $B$ の間の枝の数を $n b$, 名詞 $A$, 名詞 $B$ からのトップノードへのパスで初めてパスが一 致するノードを $\mathrm{C}$ とし，ノード $C$ とトップノードの間の枝の数を $n c$ とすると, $(n c+n c) /(n a$ $+n b)$ で与えられる。この式は, $n a, n b$ に対して $n c$ の值の大きさの割合をとったものである. $n a, n b$ に対して $n c$ の值が大きいとき, シソーラス中でのノード $C$ の位置が相対的に下の方に あることになり, 名詞 $A$ と名詞 $B$ の類似度が高いことを意味する．この手法は文献 (長尾, 佐藤, 黒橋, 角田 1996)の方法を利用している.

規則 22 で用いるコーパスは, 新聞 1 年分のもの (約 7 千万文字) を利用している。コーパス から一致部分を取り出す方法はコーパスをソートしておき二分探索で行なっている.

\section{3 解析例}

動詞の省略の補完例を図 4に示す。図4は「お願いが」の動詞の省略の解析を正しく行なっ たことを示している。これを以下で説明する。

表 1 で示した規則のうち，まず，文末が動詞の基本形などのふつうに文末になりうる表現で ないので，一つ目の規則は適用されず，動詞の省略であると解釈される，次にいつでも適用さ れる規則 16 が適用され前文の文末という候補があがる．次にコーパスを利用する規則 22 によ り，動詞「あります」が補完の候補にあがる。コーパスには他に「ある」などがあるが，これ らよりも「あります」の方が頻度が多かったので,「あります」が補完の候補にあがる．表のよ うに候補は二つあがるが，得点が最も大きい「あります」を正しく補完する.

\section{4 実験と考察}

\section{1 実験}

動詞の省略の解析を行なう前には構文解析・格解析を行なう。構文解析・格解析における誤 りのうち，動詞の省略の補完に影響を与えるものについては人手で修正した. 


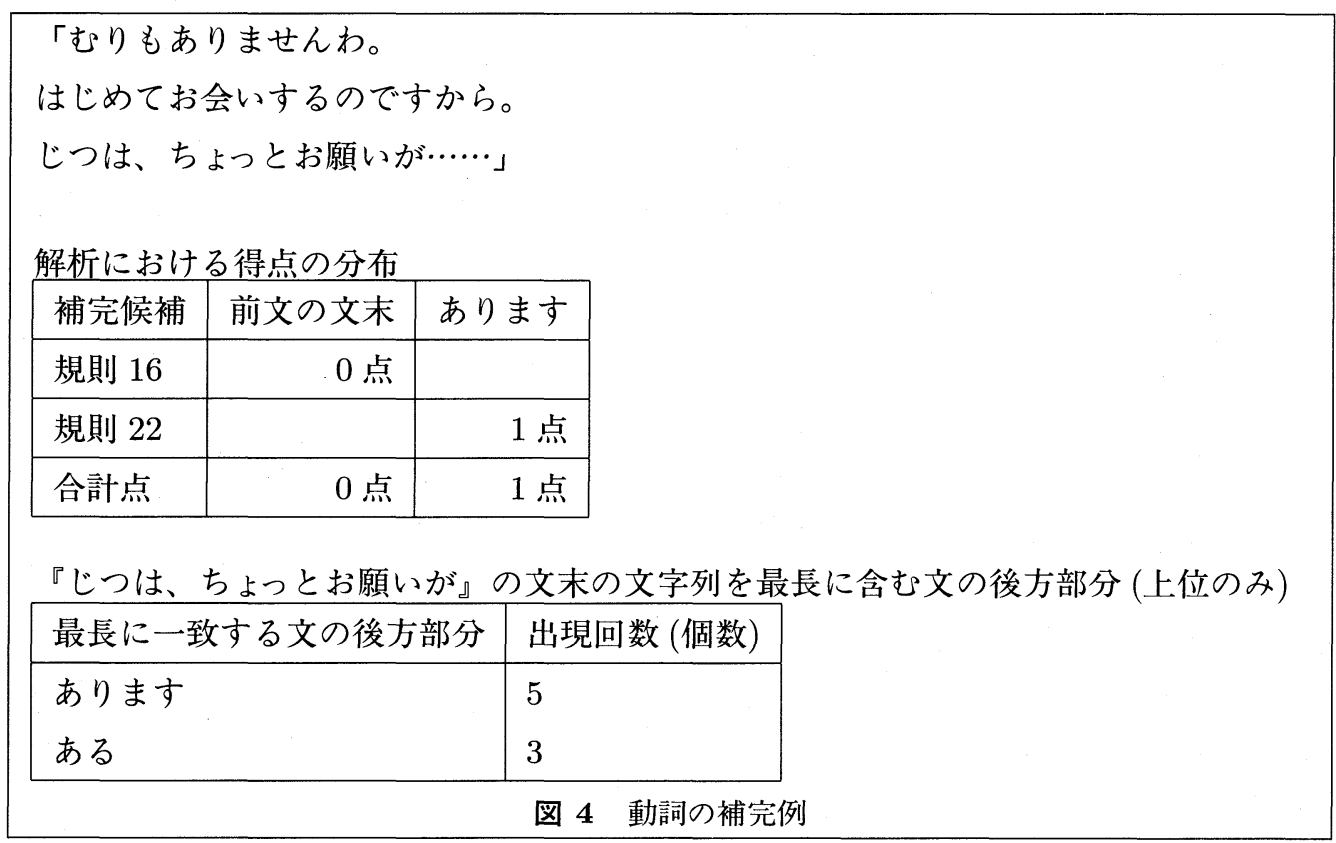

実験は小説「ボッコちゃん」(星 1971) で行なった。これは新聞などよりも小説の方が多様 な省略現象を含んでいるからである。また，実験においては実験テキストを学習サンプルとテ ストサンプルの二つに分けた。本研究の規則は学習サンプルを見て作成し，テストサンプルで はその作成した規則の有効性を調べた。本研究で提案した手法で動詞の省略の補完を行なった 結果を表 2 に示す.

本研究の実験の評価をする上で，正解の基準は以下のように緩めに設定した．動詞の省略の 補完においては，テンスやアスペクトや丁寧表現などが異なっていても補うべき動詞が正しけ れば正解とした。テンスやアスペクトなどの問題は前後の文脈や話者と聴者の間の立場上の関 係などが，影響するので，文と文の間の意味的な関係の研究や話者と聴者の間の立場上の関係 の把握の研究において行なわれるべき問題と考え，ここでは扱わなかったままた，疑問文にお

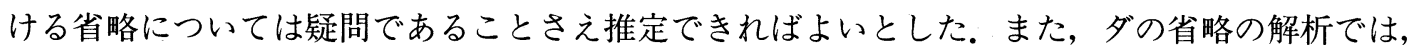
名詞を列挙している部分も「だ」を補うことができればよいとしている．また，正解がテキス ト内の動詞であっても，コーパスなどから補ったものがほぼ同様な動詞である場合は正解とし ている.

\section{2 考察}

表 2 のようにテストサンプルにおいても再現率 $84 \%$, 適合率 $82 \%$ という比較的高い精度を得 た.このことから本研究で作成した規則が有効であることがわかる. 
表 2 本研究の実験結果

\begin{tabular}{|c|c|c|c|c|}
\hline & \multicolumn{2}{|c|}{ 学習サンプル } & \multicolumn{2}{|c|}{ テストサンプル } \\
\hline & 再現率 & 適合率 & 再現率 & 適合率 \\
\hline 全分類での精度 & $92 \%(129 / 140)$ & $90 \%(129 / 144)$ & $84 \%(125 / 148)$ & $82 \%(125 / 152)$ \\
\hline テキスト内から補完 & $100 \%(57 / 57)$ & $85 \%(57 / 67)$ & $94 \%(64 / 68)$ & $81 \%(64 / 79)$ \\
\hline 倒置 & $100 \%(13 / 13)$ & $93 \%(13 / 14)$ & $100 \%(8 / 8)$ & $80 \%(8 / 10)$ \\
\hline 応答 & $100 \%(3 / 3)$ & $100 \%(3 / 3)$ & $-\%(0 / 0)$ & -\% $(0 / 0)$ \\
\hline 理由・逆接・仮定 & $100 \%(24 / 24)$ & $88 \%(24 / 2$ & $100 \%(33 / 33)$ & $85 \%(33 / 39)$ \\
\hline 補足 & $100 \%(17 / 17)$ & $74 \%(17 / 23)$ & $94 \%(23 / 27)$ & $77 \%(23 / 30)$ \\
\hline テキス। & $87 \%(72 / 83)$ & $94 \%(72 / 77)$ & $76 \%(61 / 80)$ & $84 \%(61 / 73)$ \\
\hline 疑問文 & $100 \% \quad(3 / 3)$ & $75 \%(3 / 4)$ & $-\%(0 / 0)$ & $0 \%(0 / 3)$ \\
\hline 夕゙省略 & $100 \%(54 / 54)$ & $100 \%(54 / 54)$ & $100 \%(51 / 51)$ & $96 \%(51 / 53)$ \\
\hline スル省略 & $100 \%(2 / 2)$ & $100 \%(2 / 2)$ & $-\%(0 / 0)$ & $-\%(0 / 0)$ \\
\hline その他 (常識の利用) & $72 \%(13 / 18)$ & $76 \%(13 / 17)$ & $56 \%(10 / 18)$ & $59 \%(10 / 17)$ \\
\hline 読者にも補完不能 & $0 \%(0 / 6)$ & $-\%(0 / 0)$ & $0 \%(0 / 11)$ & $-\%(0 / 0)$ \\
\hline
\end{tabular}

各規則で与える得点は学習サンプルにおいて人手で調節した。

学習サンプル \{小説「ボッコちゃん」前半分 $(2614$ 文)(星 1971) \}

テストサンプル \{小説「ボッコちゃん」後ろ半分 $(2757$ 文)(星 1971) \}

評価に適合率と再現率を用いたのは，動詞を補う必要のない文末に対してシステムが誤って動詞を 補ってしまう場合があり，この誤りを適切に調べるためである。再現率はシステムが正しく省略を 補った文末の個数を，実際に省略が存在する文末の個数で割つたもので，適合率はシステムが正し く省略を補った文末の個数を，システムが省略を補った文末の個数で割ったものである.

また，図2の分類にはない「読者にも補完不能」という分類を新たに設けた。これは，発話が途中 で中断されたものや，その文章のそこまでの読みでは読者にもまだわからないものである場合を意 味する。これらに対する補完は困難であるので, 常識を利用する方法の評価を正しく行なうために, ここの表では「その他 (常識の利用)」とは別の分類とした。全分類では,「読者にも補完不能」とい う分類を含めて精度を求めている。読者にも補完不能」は読者にも補完ができないので精度の算出 には用いない方がよいと二見思えるが,「読者にも補完不能」であるような省略が存在していること をシステムが認識する必要があるので精度に含めた。

省略現象ごとの精度では，テキスト内補完の方がテキスト外補完よりも精度がよい。これ は，テキスト内補完の場合補完する動詞の場所を特定するだけで良いので簡単であるが，テキ スト外補完の場合補完する動詞がテキスト中にないことを判定したうえ補完する動詞を知識か ら持ってこないといけないため，難しいことを意味している.

また，コーパスを利用して解析する「その他 (常識の利用)」の精度はあまり良くなかった. しかし,「その他 (常識の利用)」については解析が困難なので半分程度解析ができるだけでも価 值がある。この手法は今後コーパスが増加した際には極めて主要な手法となるだろう。また，本 稿では単なる文字列マッチングで類似度を計算していたが，意味や品詞情報を用いた類似度の 算出を行なっていく必要がある，さらには，前文との兼ね合いを調べるために，前文の文の夕 イプ (疑問文であるか否かなど) が一致する用例のみから欲しい文を探し出すなどのことも行な わないといけない.

規則を作成するために利用した学習サンプルの実験においては「その他 (常識の利用)」「読 者にも補完不能」以外の分類では再現率はすべて $100 \%$ あった，しかし，適合率については $100 \%$ な゙なものもあった。これは，推定の困難な「その他(常識の利用)」「読者にも補完不能」 
の分類にあたるものや省略・倒置が存在していないものを「その他 (常識の利用)」以外の省略・ 倒置と推定し, システムが補った省略の個数が求めるべき省略の個数を上回ったため適合率が 下がったものである。

テストサンプルにおいては「その他 (常識の利用)」以外の分類は今でも精度が高いが，詰っ たものの中にはそれぞれの規則で表層表現の利用を精密にすることで改善できるものがあった. また，次のような新しい種類の規則が必要となるものがあった.

$$
\begin{aligned}
& \text { そのとたん、私は大きな悲鳴を聞いた。 } \\
& \text { ちょうど、逃げ場のない場所で、なにかに押しつぶされてい } \\
& \text { るような、おそろしい声の…… }
\end{aligned}
$$

この例では「おそろしい声の」が前文の「大きな悲鳴」の補足となっている。これについては， 以下の規則を利用すれば今後は解析可能となる。

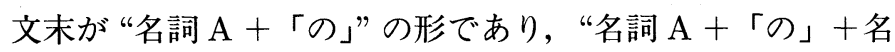

$$
\begin{aligned}
& \text { 詞 B” の形の用例を集め, 名詞 B と意味的に近い名詞が前の } \\
& \text { 文にある場合，その名詞に対する補足であると解釈する。 }
\end{aligned}
$$

\section{5 おわりに}

本研究では，表層表現と用例を用いて省略された動詞を補完するということを行なった，実 験の結果, テストサンプルで再現率 $84 \%$, 適合率 $82 \%$ の精度で解析できた. テキスト内に補完 すべき動詞がある場合は非常に精度が良かった，それに比べ，テキスト内に補完すべき動詞が ない場合はあまり良くなかった。しかし，テキスト内に補完すべき動詞がない場合の問題の難 しさから考えると，半分程度解析ができるだけでも価值があると思っている．また，コーパス が多くなり，計算機の性能もあがり大規模なコーパスが利用できるようになった際には，本稿 で提案した用例を利用する手法は重要になるだろう。

\section{参考文献}

Dalrymple, M., Shieber, S., and Pereira, F. (1991). "Ellipsis and Higher-Order Unification."

In Linguistics and Philosophy 14, pp. 399-452.

星新一 (1971). ボッコちゃん. 新潮社.

情報処理振興事業協会技術センター (1987). “計算機用日本語基本動詞辞書 IPAL(Basic Verbs) 説明書.”。

川合淳介 (1982). “日本語後略文について. 日本語学校論集, 9 号, pp. 53-74. 
Kehler, A. (1993). "A Discourse Copying Algorithm for Ellipsis and Anaphora Resolution." In Proceedings of the European Chapter of the Association for Computational Linguistics, pp. 203-212.

国立国語研究所 (1964). 分類語彙表. 秀英出版.

Kurohashi, S. and Nagao, M. (1994). "A Method of Case Structure Analysis for Japanese Sentences based on Examples in Case Frame Dictionary." IEICE Transactions on Information and Systems, E77-D (2), 227-239.

Lappin, S. and Shih, H. (1996). "A Generalized Reconstruction Algorithm for Ellipsis Resolution." In COLING '96, pp. 687-692.

村田真樹・長尾真 (1996). “名詞の指示性を利用した日本語文章における名詞の指示対象の推 定.”言語処理学会論文誌, 3 (1).

村田真樹・長尾真 (1997a). “用例や表層表現を用いた日本語文章中の指示詞・代名詞・ゼロ代 名詞の指示対象の推定.”言語処理学会論文誌, 4 (1).

村田真樹・長尾真 $(1997 b)$. “意味的制約を用いた日本語名詞における間接照応解析.”言語処理 学会論文誌, $4(2)$.

長尾真, 佐藤理史, 黒橋禎夫, 角田達彦 (1996). 自然言語処理, 岩波講座ソフトウェア科学, 15 巻. 岩波書店.

高橋太郎 (1993). “省略によってできた述語形式.”日本語学, 12 巻.

渡辺靖彦, 黒橋禎夫, 長尾畺 (1992). “IPAL 辞書と分類語彙表を用いた単語意味辞書の作成.” 情 報処理学会第 45 回全国大会予稿集, $6 \mathrm{~F}-8$.

山本幹雄, 小林聡, 中川聖一 (1992). “音声対話文における助詞落ち・倒置の分析と解析手法.” 情報処理学会論文誌, 33 (11), 1322-1330.

\section{略歴}

村田 真樹: 1993 年京都大学工学部卒業. 1995 年同大学院修士課程修了. 1997 年同大学院博士課程修了, 工学博士. 現在, 京都大学にて日本学術振興会リ サーチ・アソシエイト。自然言語処理, 機械翻訳の研究に従事.

長尾 真: 1959 年京都大学工学部電子工学科卒業. 工学博士. 京都大学工学部 助手, 助教授を経て, 1973 年より京都大学工学部教授. 国立民族学博物館 教授を兼任 $(1976$ - 1994). 京都大学大型計算機センター長 $(1986-1990)$, 日本認知科学会会長 $(1989-1990)$, パターン認識国際学会副会長 $(1982-$ 1984), 日本機械翻訳協会初代会長 $(1991-1993)$, 機械翻訳国際連盟初代会 長 $(1991$ - 1993)，電子情報通信学会副会長 $(1993$ - 1995)．情報処理学会副 会長 $(1994$ - 1996). 京都大学附属図書館長 $(1995$ - 1997). 京都大学大学院 工学研究科長 $(1997-)$. パターン認識, 画像処理, 機械翻訳, 自然言語処理 
等の分野を並行して研究.

(1996 年 12 月 16 日 受付)

(1997 年 5 月 8 日 再受付)

(1997 年 7 月 18 日 採録) 